\title{
Mucormycosis Mimicking Tracheal Tumor: A Case Report
}

\author{
Reza Ansari $^{1}(\mathbb{D})$ Payman Dabirmoghaddam ${ }^{1}(\mathbb{D})$ Maryam Lotfi $^{2}(\mathbb{D})$ Mina Gheitani $^{3}(D)$ \\ Saeed Sohrabpour ${ }^{1}(\mathbb{D})$, Farrokh Heidari ${ }^{*}(\mathbb{D})$
}

1. Department of Otorhinolaryngology and Head \& Neck Surgery, Amir-Alam Hospital, Tehran University of Medical Sciences, Tehran, Iran.

2. Department of Pathology, Amir-alam Hospital, Tehran University of Medical Sciences, Tehran, Iran

3. Department of Internal Medicine, Shahid-beheshti Hospital, Qom University of Medical Sciences, Qom, Iran

4. Department of Otorhinolaryngology and Head \& Neck Surgery, Amir-Alam Hospital, Tehran University of Medical Sciences, Tehran, Iran

$10.30699 / \mathrm{ijmm} \cdot 15.2 \cdot 247$

ABSTRACT

A 49-year-old woman with a history of diabetes mellitus (DM), and hypothyroidism referred to the emergency ward complaining of shortness of breath which had lasted for three weeks. Due to inspiratory and expiratory stridor in the clinical examination, a tracheal lesion was proposed for her. In computed tomography (CT) scan (without contrast) of the neck and chest, a lesion resembling a malignant tracheal tumor was observed spreading around the cervical trachea. Subsequently, the patientchr('39')s respiratory distress worsened and she underwent tracheostomy under general anesthesia. During tracheostomy, a white to creamy lesion that resembled necrosis with extensive granulation was seen in cervical trachea, and a biopsy was taken. Histopathological reports showed evidence of acute and chronic inflammation, in necrotic background, along with aseptate fungi which confirmed mucormycosis. Initially, intravenous liposomal amphotericin-B was selected as an antifungal drug which was discontinued due to drug-induced acute renal failure. Posaconazole suspension was replaced as an antifungal drug. After about six weeks, the patient was discharged from the hospital in good general condition. Contrary to few previous studies on mucormycosis of the trachea and lower airways, tracheal disease was limited in our patient; therefore, we avoided debridement of the conflict site and tried to control the disease by controlling the underlying disease (DM), and antifungal therapy. Finally, the desired result was achieved. It should be noted that all patients who have been reviewed in the previous published studies have had a wider conflict sites compared to our patient. Therefore, due to the lack of standard treatment for this disease, our therapeutic approach in this study can be considered as an option in limited and localized cases.

Keywords: Fungal infection, Mucormycosis, Posaconazole, Trachea, Tracheostomy

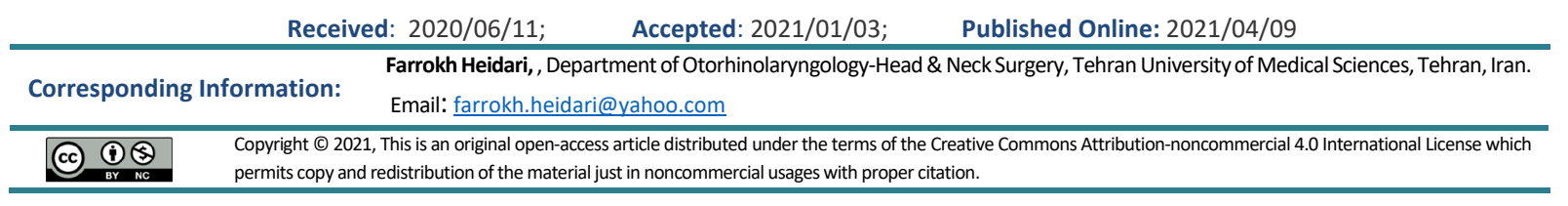

Use your device to scan and read the article online

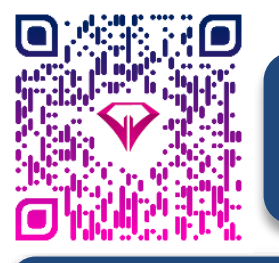

Ansari R, Dabirmoghaddam P, Lotfi M, Gheitani M, Sohrabpour S, Heidari F. Mucormycosis mimicking Tracheal Tumor: a case report. Iran J Med Microbiol. 2021; 15 (2) :247-256

Download citation: BibTeX | RIS | EndNote I Medlars | ProCite I Reference Manager | RefWorks
Send citation to:
Mendeley
(2) Zotero
(1) RefWorks

\section{Introduction}

Invasive mucormycosis is a fatal opportunistic infection caused by the Mucoraceae family. Various underlying diseases such as diabetes mellitus (DM) or other immunocompromised diseases, especially hematological malignancies can lead to the invasion of this fungus (1). 
Invasion to trachea and larynx is one of the rarest manifestations of this infection leading to airway obstruction and life-threatening complications $(2,3)$

Diagnosis is based on microscopic histopathology, and the recommended drug treatment is liposomal amphotericin while posaconazole remains for salvage therapy (4).

In this manuscript, we report our experience in managing a patient with tracheobronchial mucormycosis. We hope our study can provide physicians with a solution for similar cases.

\section{Case Presentation}

A 49-year-old woman with DM, and hypothyroidism (controlled by metformin, and levothyroxine, respectively) came in complaining about fatigue, myalgia, mild fever, and progressive shortness of breath for about three weeks. On initial physical examination, she had moderate to severe respiratory distress and stridor with supra-sternal retraction. An inspiratory and expiratory stridor was heard in auscultation of the lungs. The patient did not have the necessary cooperation to perform the indirect laryngoscopy.

Therefore, it was decided to have an electrocardiogram (ECG) and computed tomography (CT) scan of the neck and chest without contrast.

The ECG was normal and the patient was sent to the radiology ward for the $\mathrm{CT}$ scan.

The CT scan revealed intraluminal lesions and inflammation in the patient's subglottic and cervical trachea, which led to the possibility of a malignant tumor due to infiltration around the trachea (Figure 1).

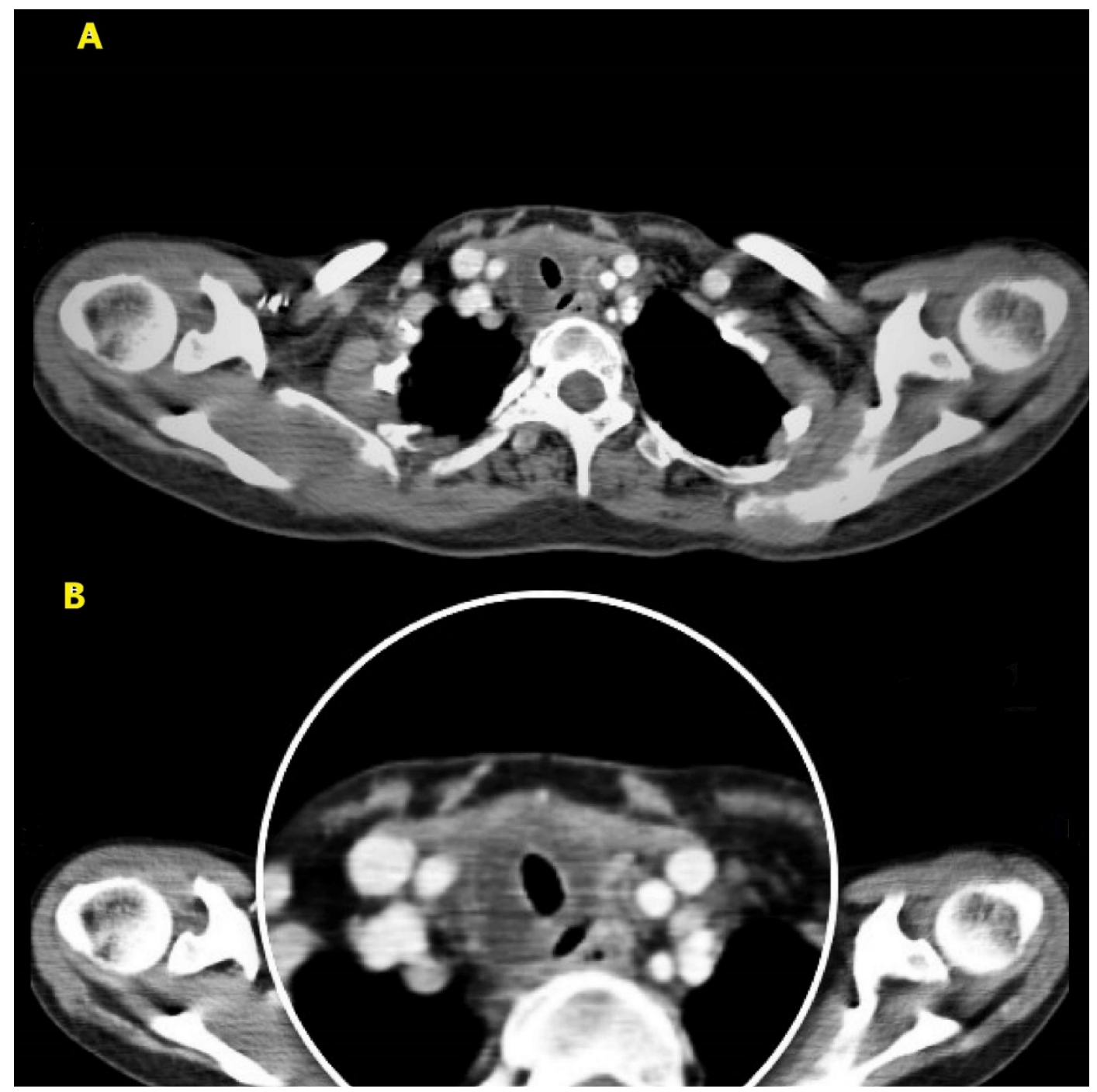

Figure 1. a. Narrowing lumen of cervical trachea by an intraluminal lesion with inflammation and infiltration to the tissues around of trachea (axial view). b. Axial view of lumen of trachea with magnification. 
As the dyspnea worsened, the patient underwent rigid and flexible bronchoscopy, and cervical esophagoscopy under general anesthesia.

There was no obvious lesion on laryngoscopy. In bronchoscopy, 2-cm-long white to creamy lesions containing granulation and necrotic tissue were seen in the trachea $(3 \mathrm{~cm}$ below the patient's true vocal cords (TVCs)), circumferentially. A Part of the anterior wall of the trachea was necrotic.

Flexible bronchoscopy (Figure 2) and CT-scan showed no evidence of lung involvement and the disease was isolated in proximal of trachea.

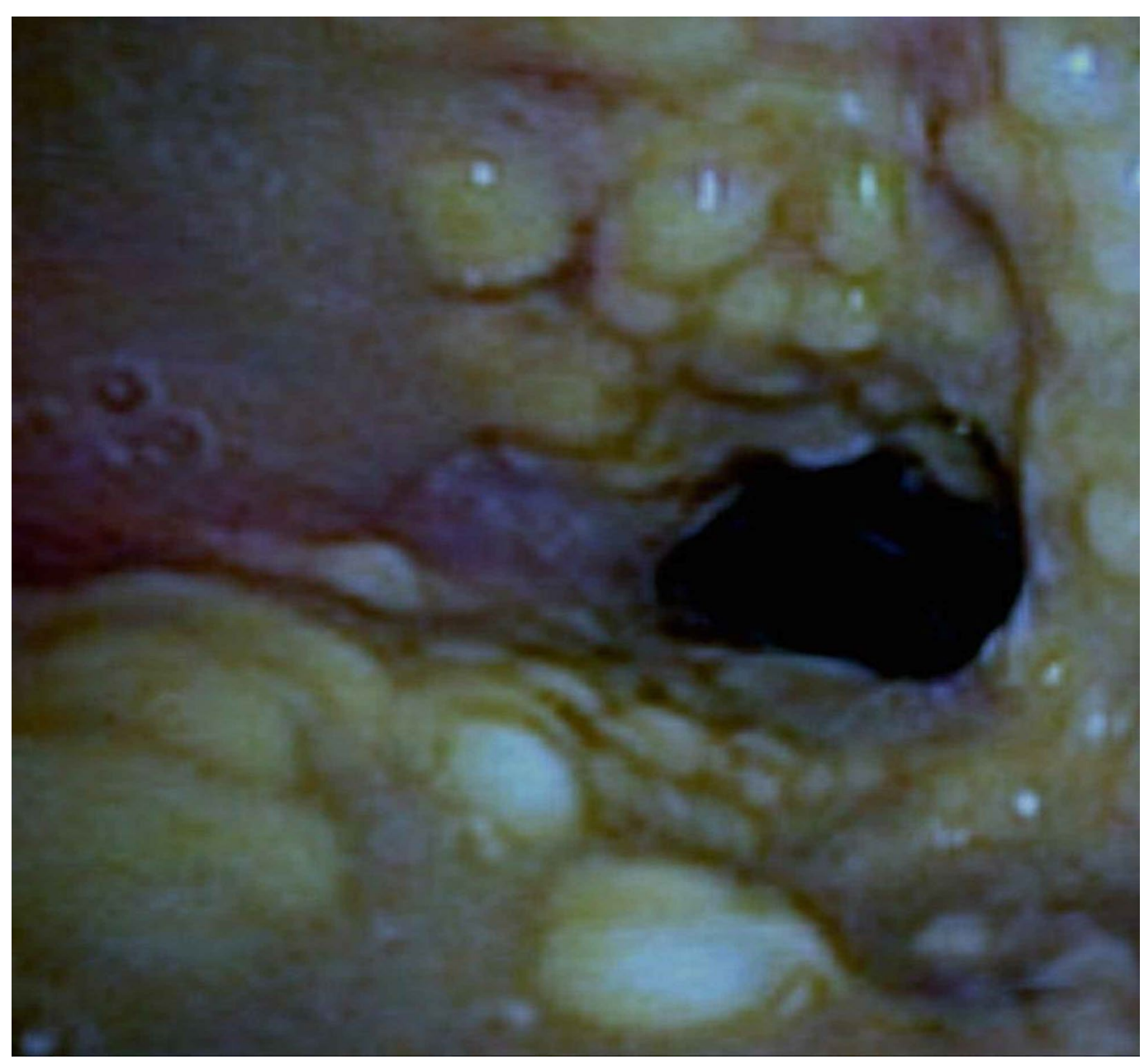

Figure 2. The white to creamy tissue in lumen of cervical part of trachea (flexible endoscopy image).

Then, the patient underwent esophagoscopy, in which the cervical esophagus was completely inflamed and purulent discharge was seen. To prevent esophagus perforation, she kept NPO (nothing by mouth) and at the same time, she underwent jejunostomy. Due to the extension of the disease, it was decided to place a tracheostomy between the third and fourth rings of trachea. From the anterior wall of the trachea during tracheostomy, a biopsy was sent for pathology and until the patient's pathology results were prepared, she was treated with vancomycin ( $1 \mathrm{gr} / \mathrm{bid}$ ) and meropenem (1gr/TDS). The patient's high blood sugar was treated with insulin for further control.

In pathology slides, some broad aseptate fungal elements were seen in a necrotic background that confirmed mucormycosis (Figure 3a yellow arrows). Fragments of the respiratory mucosa with acute and chronic inflammation were seen (Figure 3b). 


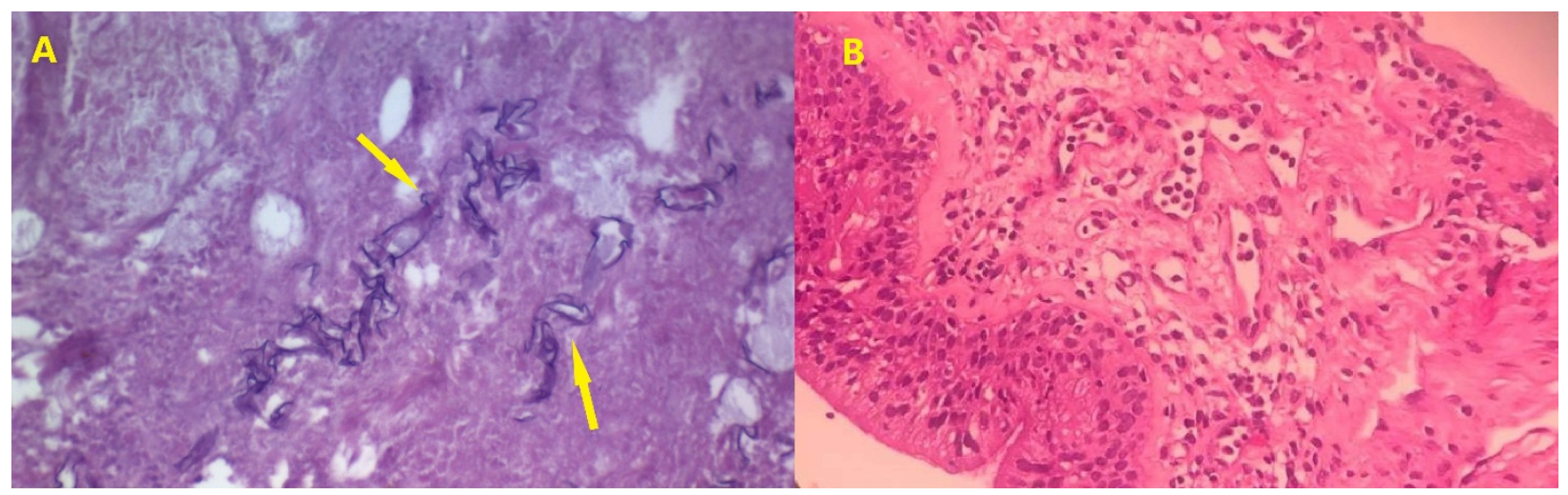

Figure 3. a. Presence of some broad aseptate fungal elements (mucormycosis) marked by yellow arrows, in a necrotic background (yellow arrows). b. Fragments of the respiratory mucosa with acute and chronic inflammation.

According to the pathology report, an infectious disease specialist started liposomal amphotericin-B $(3 \mathrm{mg} / \mathrm{Kg} /$ day) therapy for the patient. After three days, the patient developed a cutaneous rash, and the patient's initial level of serum creatinine, which was normal $(1 \mathrm{mg} / \mathrm{dl})$, reached $6.4 \mathrm{mg} / \mathrm{dl}$. Interstitial nephritis caused by the amphotericin- $B$ was suggested, and by a nephrologist's advice, vancomycin was discontinued and meropenem was adjusted. The patient also became severely hydrated. After two weeks, the patient's serum creatinine level returned to its initial level. Liposomal amphotericin was also discontinued. According to the advice of an infectious disease specialist and the study of Spellberg et al. (5), posaconazole suspension began (5cc (200mg)/QID), and continued until clinical signs, including fever and constitutional symptoms, disappeared and there was no concern about recurrence. After four weeks of treatment and improvements the patient's condition, bronchoscopy and esophagoscopy were performed again under general anesthesia. Inflammation of the esophagus had disappeared. Total Stenosis of trachea was seen $3 \mathrm{~cm}$ below the TVCs. Then, the esophagogram with barium was performed for the patient and the report was normal. Therefore the oral feeding began for her and the jejunostomy was removed. The patient was discharged and advised to take two posaconazole suspensions for two weeks at home and control DM with insulin under the supervision of an endocrinologist.

About 18 months after the first onset of the disease, she underwent an end-to-end anastomosis of the cervical trachea, removing four cartilaginous rings, and while a year has passed since her operation, she no longer has a problem

\section{Discussion}

Isolated tracheal mucormycosis (TM) is very rare and the current knowledge of TM comes from several case reports or relatively small case series. Early diagnosis and antifungal therapy are the major factors of prognosis (6).
Dealing with mucormycosis in other parts of the body, it is recommended to use aggressive debridement in various studies (6-8).

Fortunately, due to the isolation of the disease in the trachea and the lack of involvement of the lower airways in our case, which was seen on flexible bronchoscopy and CT scans of the patient's lungs, we did not find debridement of necrotic tissue necessary. This was because of the possibility of complications such as loss of intact tracheal cartilage rings and esophageal perforation. Also, the loss of cartilage that could be cured with medical treatment may make it more difficult for the next possible stage of surgery, such as end-to-end anastomosis of trachea. However, in some studies, surgical or endoscopic debridement was performed $(2,3,6,8,9)$.

Due to the respiratory conditions, it was decided to install a tracheostomy for her, to ensure her breathing. In most tracheobronchial mucormycosis reports, such as ours, a tracheostomy has been implanted for the patient $(8,10)$.

\section{Conclusion}

Contrary to few previous studies on mucormycosis of the trachea and lower airways, tracheal disease was limited in our patient; therefore, we avoided debridement of the conflict site and tried to control the disease by controlling the underlying disease (DM), and antifungal therapy. Finally, the desired result was achieved.

It should be noted that all patients who have been reviewed in the previous published studies have had a wider conflict sites compared to our patient.

Therefore, due to the lack of standard treatment for this disease, our therapeutic approach in this study can be considered as an option in limited and localized cases.

\section{Acknowledgment}

None. 


\section{Funding}

None.

\section{Conflict of Interest}

Authors declared no conflict of interests.

\section{Ethical statement}

All ethical standards are met in this study.

\section{Patient's Consent}

A written consent was obtained from the patient. 


$$
\begin{aligned}
& \text { مجله ميكروبشناسى يزشكى ايران } \\
& \text { سال ها _ شماره r _ فروردين و ارديبهشت .. } \\
& \text { Journal homepage: www.ijmm.ir }
\end{aligned}
$$

\section{موكورمايكوزيس مقلد تومور تراشه: كزارش موردى}

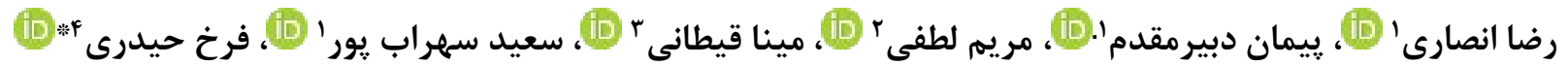

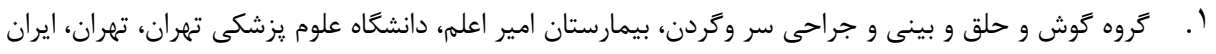

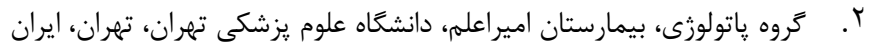

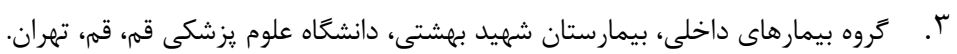

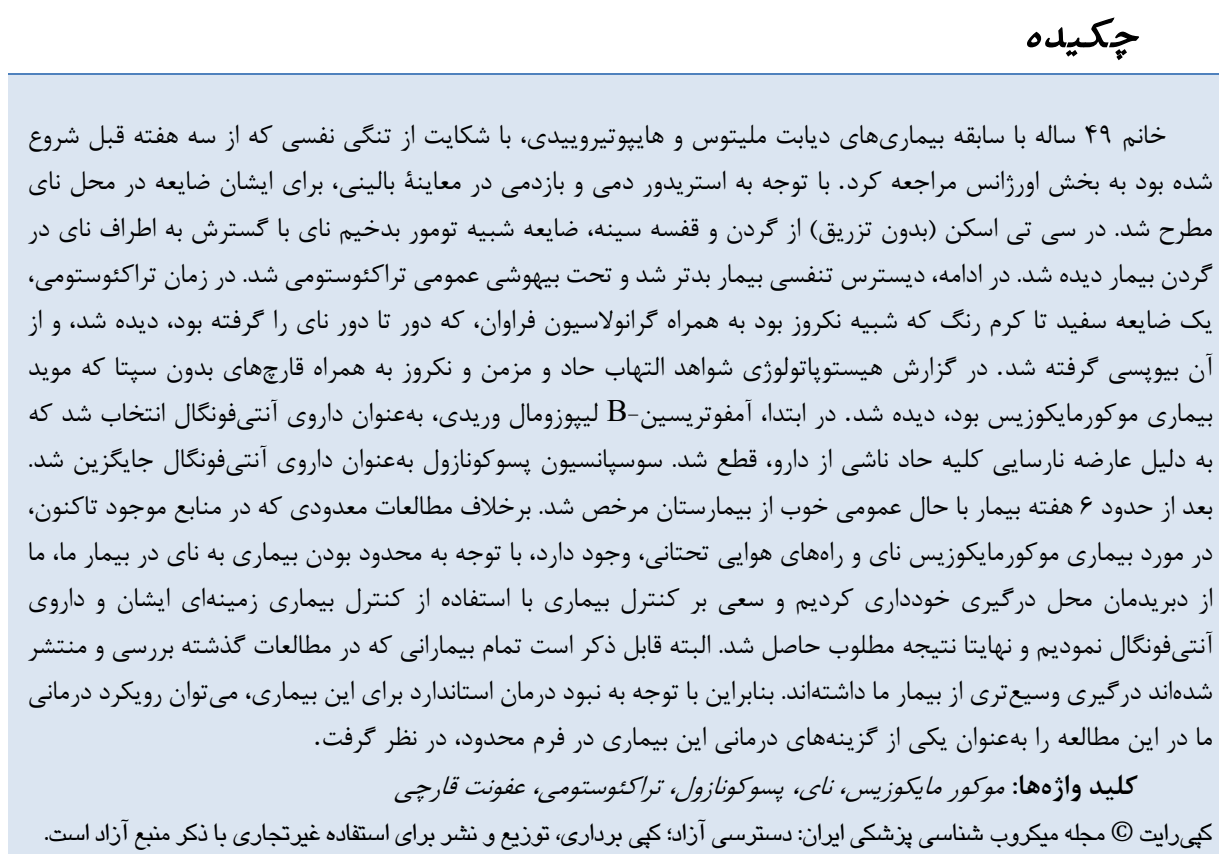

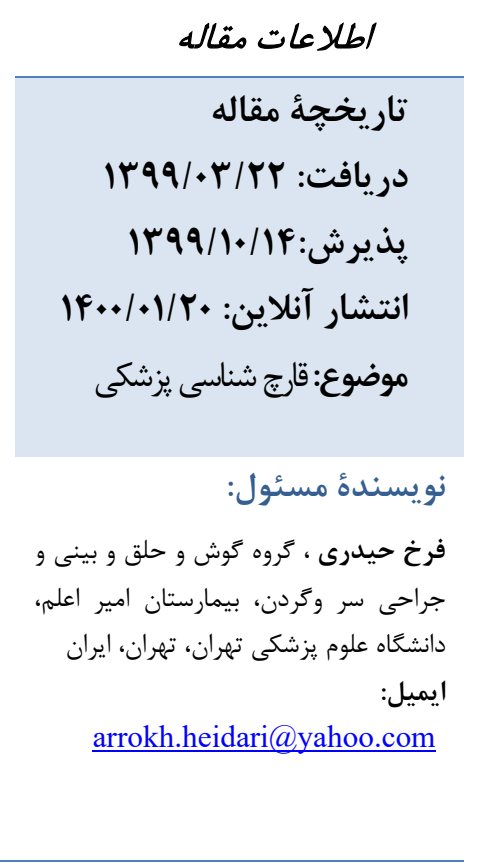

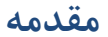

در اين دست نوشته، ما تجربه خود را در يك بيمار با

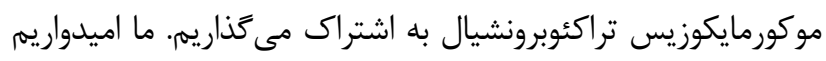

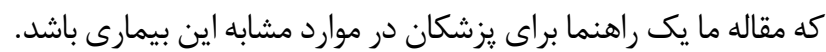

\section{كزارش مورد}

خانم qq ساله با ديابت مليتوس و هاييوتيروييدى كه تحت درمان با متفورمين و لووتيروكسين بود، با شكايت از شروع

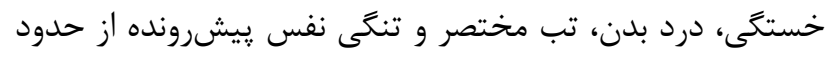

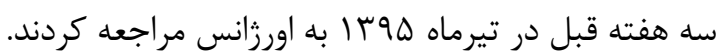

در معاينه بالينى اوليه، ديسترس تنفسى متوسط تا شديد به همراه استريدور و رتراكسيون فوق استرنال داشت. در سمع ريه، دئه
موكورمايكوزيس مهاجم ، يك عفونت فرصت طلب كشنده

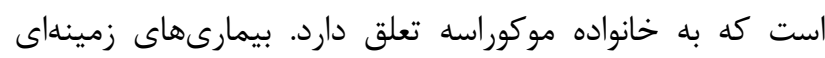

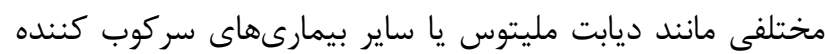

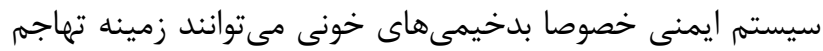

$$
\text { اين قارج را فراهم كنند (1) - (1) }
$$

تهاجه به ناى و حنجره يكى از نادر ترين تظاهرات اين عفونت

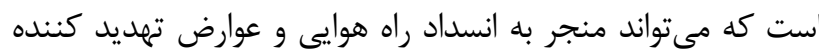

$$
\text { حيات فرد منجر شود (T، Y) (Y). }
$$

تشخيص اين بيمارى بر اساس بافتشناسى ميكروسكويى است يسوكونازول براى خط آخر درمان باقى مىماند (F).

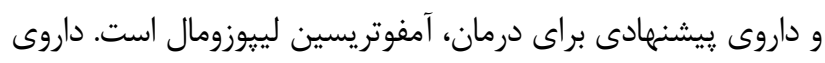


و بيمار براى انجام سى تى اسكن به بخش راديولوزى فرستاده شد.

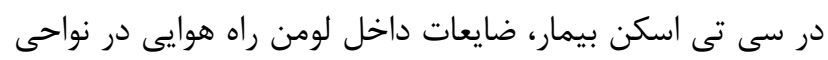

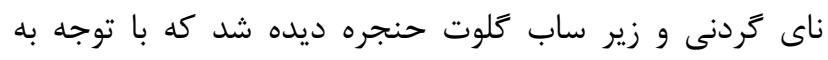

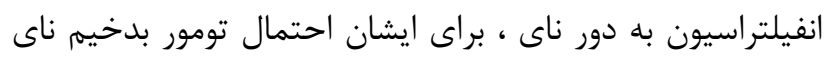

مطرح شد (شكل ().
استريدور دمى و بازدمى شنيده مى شى بـ بيمار همكارى مناسب براى انجام لاركوسكوبى غير مستقيم را نداشت. بنابراين تصميم به انجام EKG و سى تى اسكن از قفسه

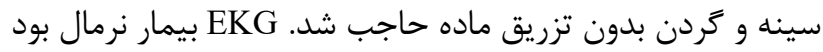
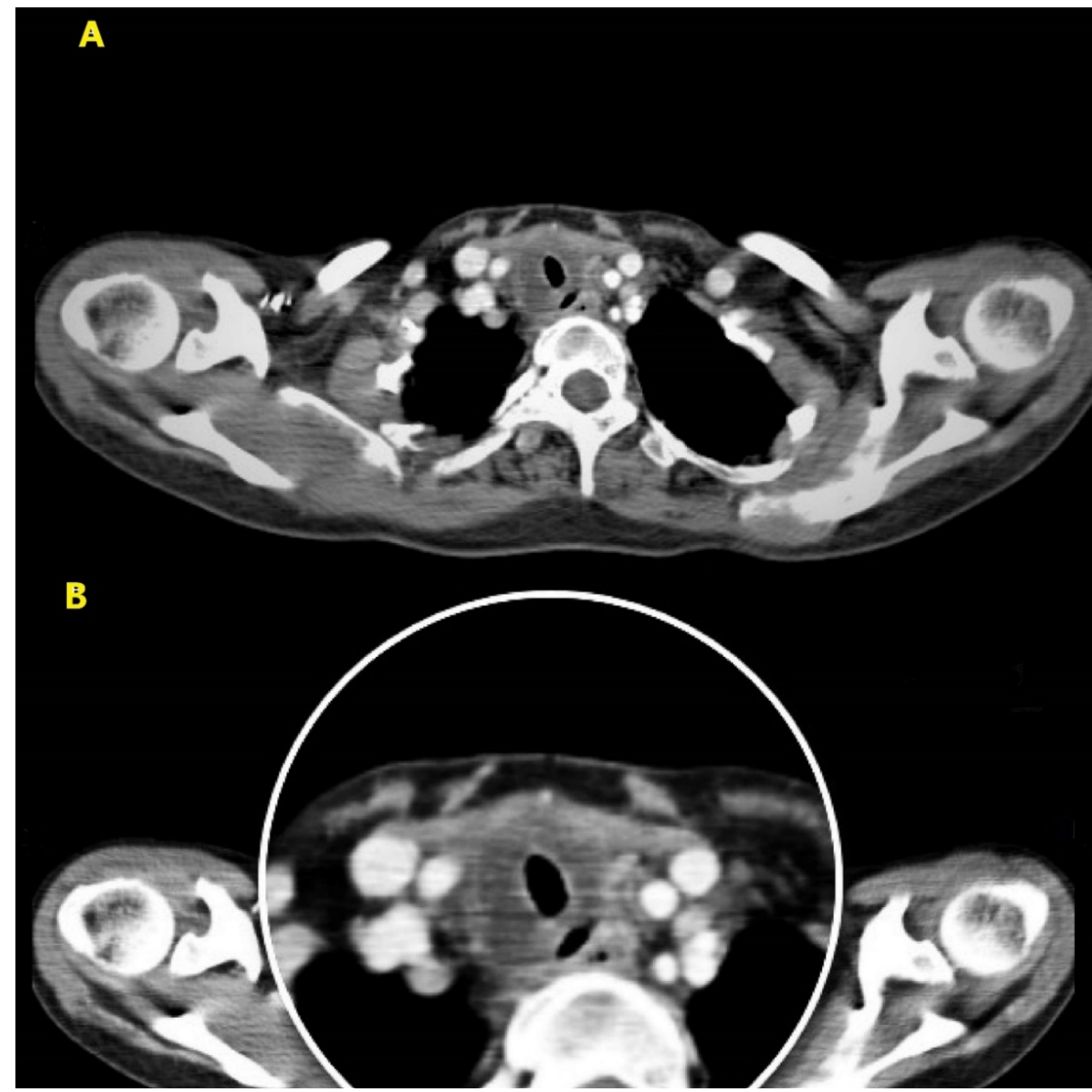

شكل ا. A: تنغَ شدن ناى در قسمت كردن به علت ضايعه داخل لومن و التهاب و انفيلتراسيون اطراف ناىB : همان ضايعه با بزر كنمايى بيشتر

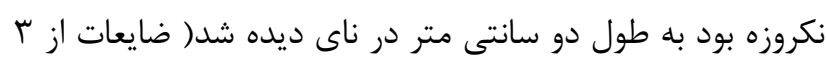

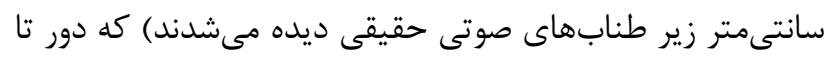

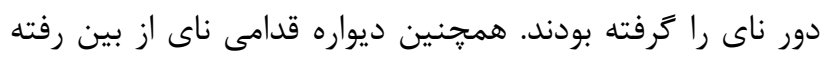

بود.
هنخامى كه ديسترس تنفسى او بدتر شد، بيمار به اتاق عمل

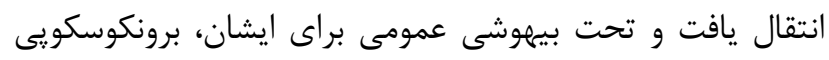

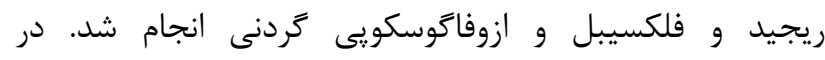

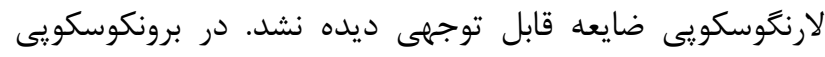

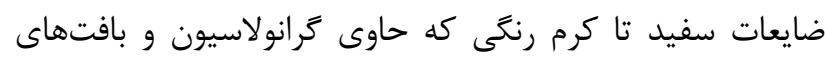




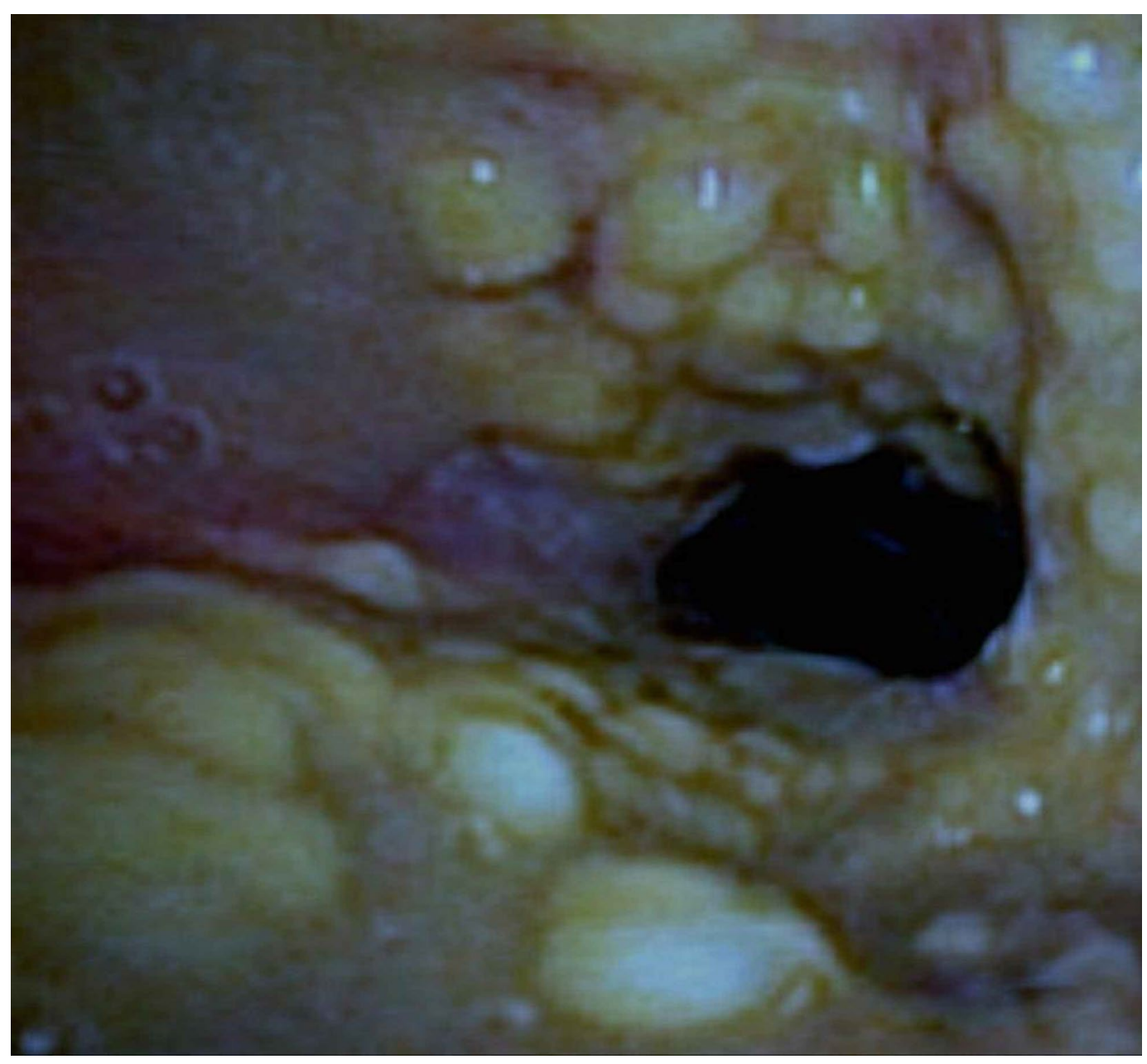

شكل r. بافت سفيد تا خامه اى در لومن قسمت كردنى رحم (flexible endoscopy image).

قدامى ناى بيويسى به عمل آمد و تا زمانى كه جواب ياتولوزى

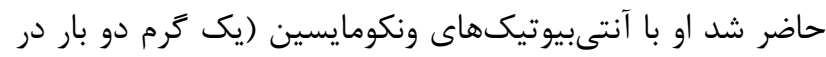

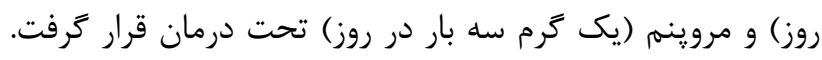
براى كنترل بيشتر قند خون او، از انسولين تزريقى استفاده شد. در اسلايدهاى پֶاتولوزى، تعدادى قارج بدون سيتا در بافت

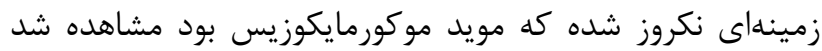

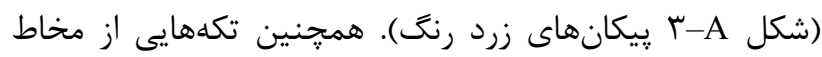

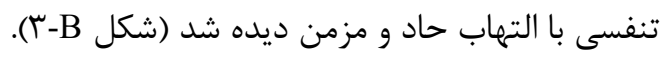

برونكوسكويى فلكسيبل (شكل r) و سى تى اسكن نشان دادند كه شواهدى از دركيرى ريه وجود ندارد. يس از آن آن ايشان

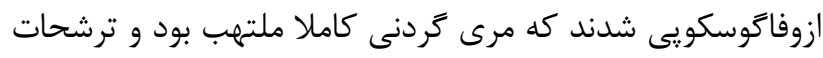

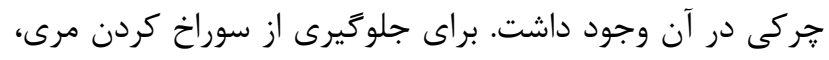

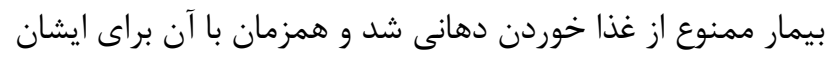
ززنوستومى تعبيه شد.

با توجه به كسترش بيمارى براى ايشان تصميم كرفتيهم كه

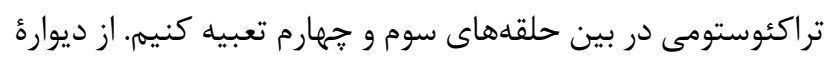




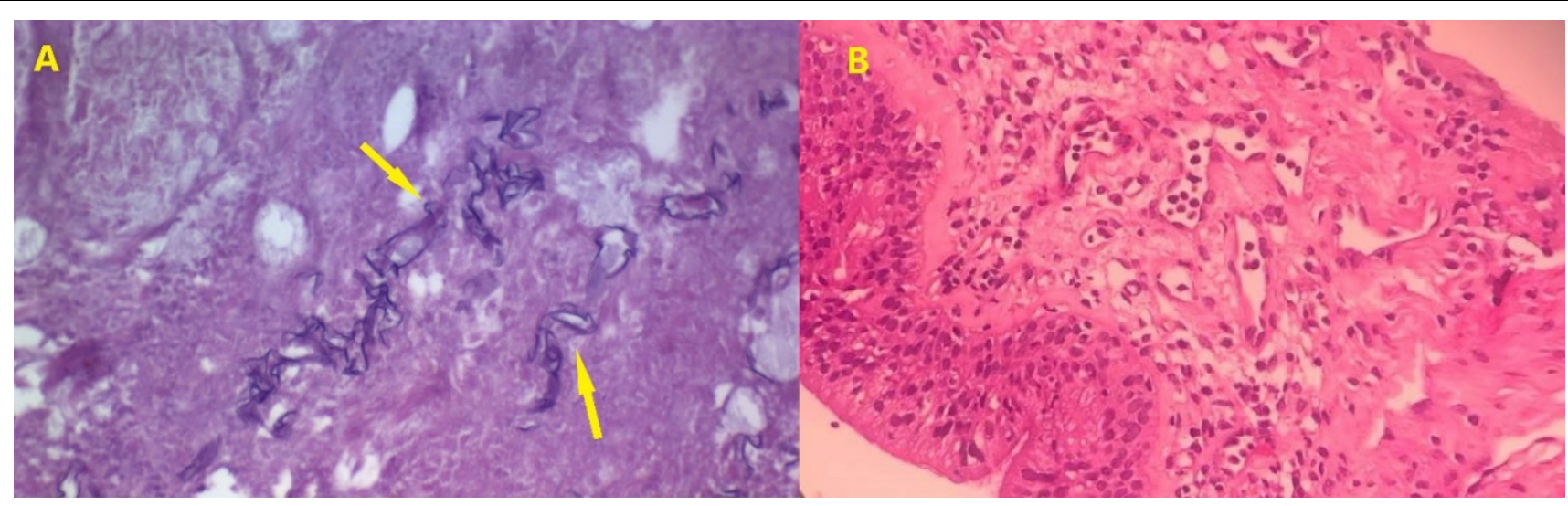

شكل r. A : :حضور قارج بدون سيتا (موكور مايكوزيس) درون زمينهاى از نكروز كه با فلش هاى زرد رنكَ مشخص شده است. B: قسمت هايى از مخاط تنفسى همراه با التهاب حاد و مزيكن يكن

ويزيت نهايى كه حدودا يكسال از عمل ايشان كذشته بود ايشان مشكلى را ذكر نكردند.

\section{بحث}

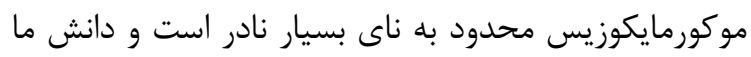

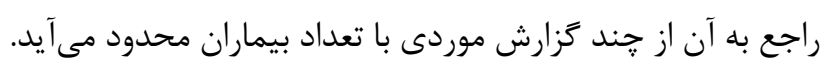

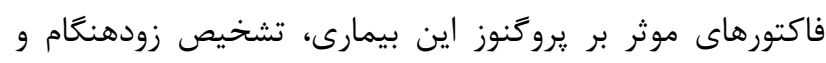

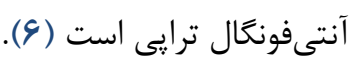

در مقايسه با موكورمايكوزيس قسمتهاى ديكر بدن، ييشنهاد به دبريدمان شديد و خشن در مطالعات مختلفى شده

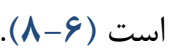

خوشبختانه، با توجه به محدود بودن دركيرى بيمارى در

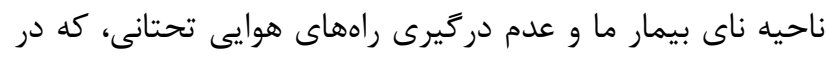

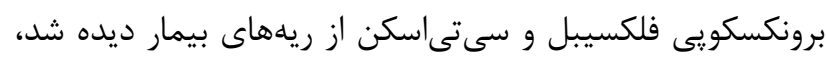

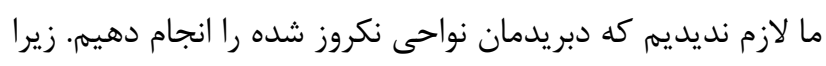

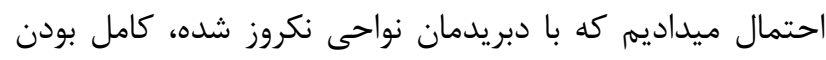

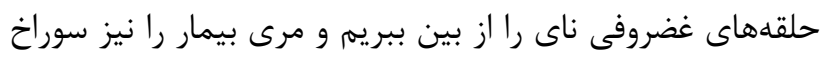
كنيم.

همجنين از دست دادن غضروف بيشتر با دبريدمان،

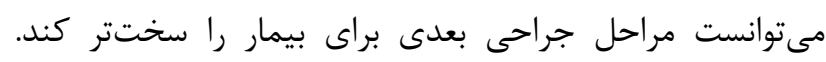

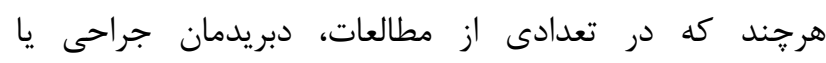

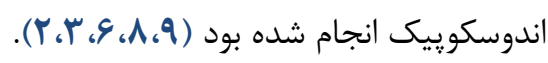
با توجه به وضعيت تنفسى ايشان، تصميم كرفتيم كه براى

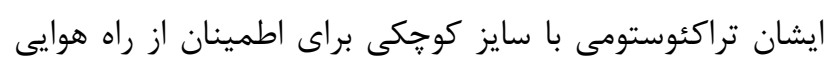

با توجه به كزارش پاتولوزى، متخصص بيمارىهاى عفونى

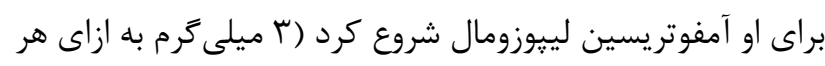

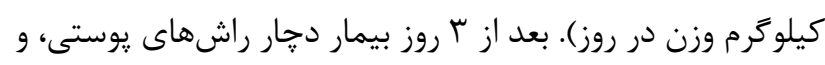

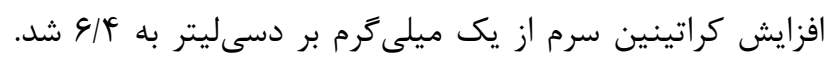

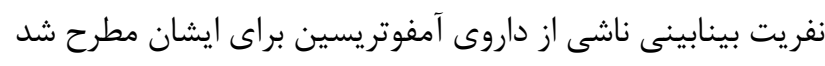

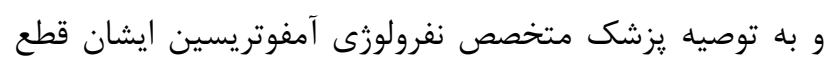

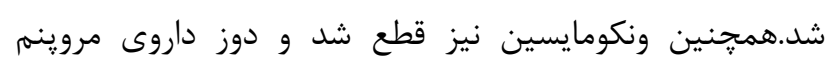
تصحيح شد. هيروترايى براى بيمار انجام شد. بعد از دو هفته كراتينين

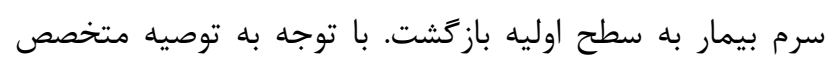

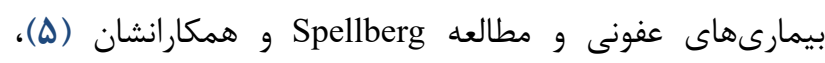

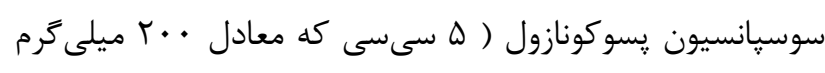

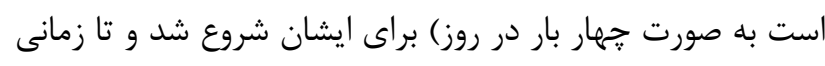

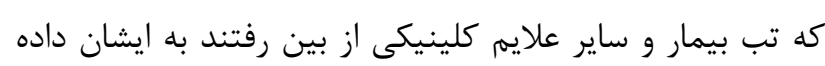

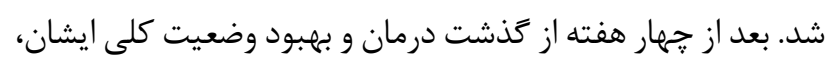
تحت برونكوسكويى و ازوفاكوسكوبى مجدد قرار كرفتند. التهاب

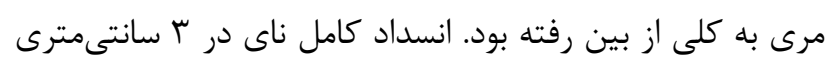

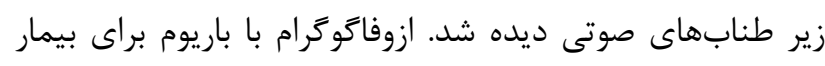

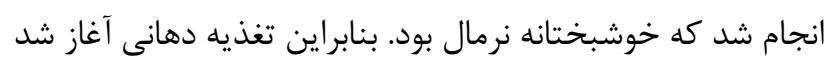

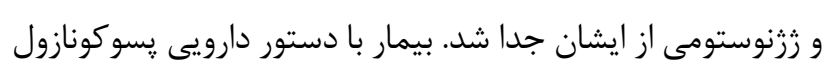

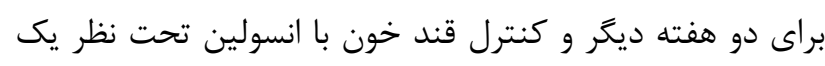
متخصص غدد، مرخص شد.

حدود 11 ماه بعد از شروع بيمارى، ايشان تحت عمل

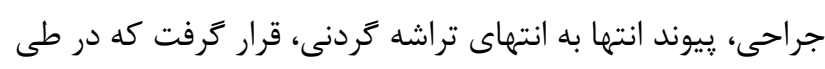

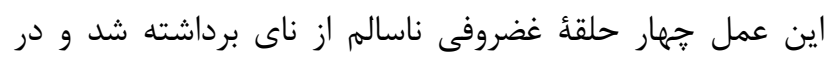




$$
\begin{aligned}
& \text { بيشتر راه هوايى آنها نسبت به بيمار اين مطالعه بوده است. بنابراين }
\end{aligned}
$$

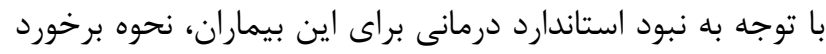

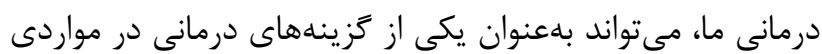

$$
\begin{aligned}
& \text { كه موكورمايكوزيس محدود و لو كاليزه است، باشد. } \\
& \text { سياسخز ارى }
\end{aligned}
$$

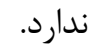

$$
\begin{aligned}
& \text { تعارض در منافع } \\
& \text { نويسندًان هيجَّونه تعارضى در منافع كَزارش نكردند. }
\end{aligned}
$$

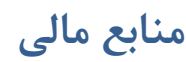

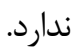

$$
\begin{aligned}
& \text { مناسب انجام دهيم. تقريبا در تمام كزارشات موكورمايكوزيس } \\
& \text { تراكئوبرونشيال مانند مورد ما تراكئوستومى تعبيه شده بود. }
\end{aligned}
$$

$$
\text { نتيجهَ }
$$

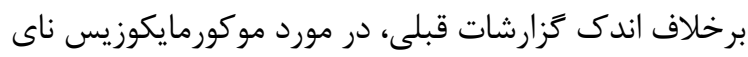

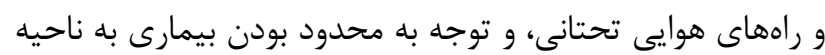

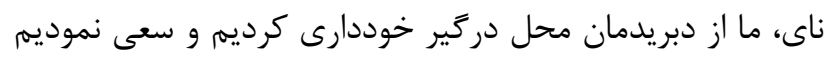

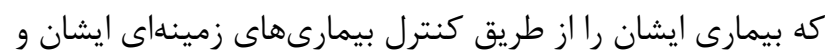

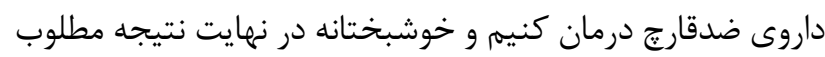

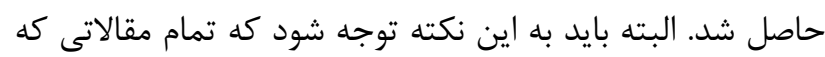

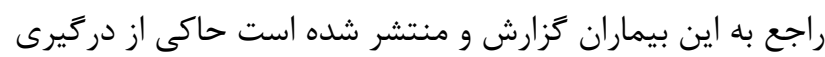

8. Mohindra S, Gupta B, Gupta K, Bal A. Tracheal Mucormycosis Pneumonia: A Rare Clinical Presentation. Respiratory Care. 2014;59:e178 - e81. [DOI:10.4187/respcare.03174] [PMID]

9. He R, Hu C, Tang Y, Yang H, Cao L, Niu R. Report of 12 cases with tracheobronchial mucormycosis and a review.

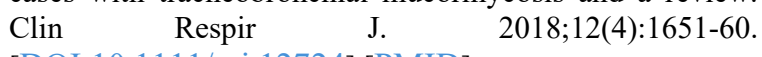
[DOI:10.1111/crj.12724] [PMID]

10. Wolf O, Gil Z, Leider-Trejo L, Khafif A, Biderman P, Fliss DM. Tracheal mucormycosis presented as an intraluminal soft tissue mass. Head \& Neck. 2004;26(6):541-3. [DOI:10.1002/hed.20055] [PMID]

3. Mattioni J, Portnoy J, Moore J, Carlson D, Sataloff R. Laryngotracheal mucormycosis: Report of a case. Ear, nose, $\&$ throat journal. 2016;95:29-39.

4. Cornely OA, Arikan-Akdagli S, Dannaoui E, Groll AH, Lagrou K, Chakrabarti A, et al. ESCMID and ECMM joint clinical guidelines for the diagnosis and management of mucormycosis 2013. Clin Microbiol Infect. 2014;20 Suppl 3:5-26. [DOI:10.1111/1469-0691.12371] [PMID]

5. Spellberg B, Walsh TJ, Kontoyiannis DP, Edwards J, Jr., Ibrahim AS. Recent advances in the management of mucormycosis: from bench to bedside. Clin Infect Dis. 2009;48(12):1743-51. [DOI:10.1086/599105] [PMID] [PMCID]

6. Brown RB, Johnson JH, Kessinger JM, Sealy WC. Bronchovascular mucormycosis in the diabetic: an urgent surgical problem. Ann Thorac Surg. 1992;53(5):854-5. [DOI:10.1016/0003-4975(92)91450-N]

7. Hashemzadeh S, Tubbs RS, Fakhree MBA, Shoja MM. Mucormycotic pseudoaneurysm of the common carotid artery with tracheal involvement. Mycoses. 2008;51(4):34751. [DOI:10.1111/j.1439-0507.2007.01487.x] [PMID] 